\title{
Jak to ta škola dělá? \\ (Klíčové faktory úspěšného zapojení rodičovských dobrovolníků do každodenní práce školy. Exploratorní případová studie Mezinárodní školy v Haagu).
}

\author{
How does the school do it?
}

(The key success factors for engaging parent volunteers into a school's day-to-day life. The exploratory case study of The International School of The Hague).

\author{
Magdalena Marešová
}

\begin{abstract}
Abstrakt: Exploratorní případová studie Mezinárodní školy v nizozemském Haagu (dále PS1) se ptá, jak a proč „funguje“ téma rodičovských dobrovolníků v hloubi jedné školy. Autoři nedávné metaanalýzy zkoumající teoreticko-metodologické aspekty problematiky (Bakker a Denessen, 2007) doporučují pro získání relevantních odpovědí využití kvalitativního prŕstupu, založeného na interpretaci hloubkových rozhovorů. Ty byly v PS1 provedenyv během dvou měsíců a vynesly data od tří (triangulovaných) skupin informantů: vedení školy, učitelů a rodičů-dobrovolníků $(n=2+10+18)$. Tato studie popisuje získaný datový soubor (cca 16 hodin audiozáznamů a 145 stran přepisu) a naznačuje možnosti jeho interpretace. Finálním výsledkem bude vytvoření teorie o tom, které faktory se podílejí na úspěšném zapojení rodičovských dobrovolníků do každodenního života školy.
\end{abstract}

Klíčová slova: rodičovský dobrovolník, mezinárodní škola, polostrukturované rozhovory

\begin{abstract}
The exploratory case study of The International School of The Hague will ask how and why the topic of volunteering parents ,works" in depth of a particular school. A recent metaanalysis on the theoretical and methodological framework of the topic ((Bakker et Denessen, 2007) suggests using the in-depth interviews could bring relevant answers. The interviews were carried on within two months, resulting in data from 3 sets of (triangulated) informants: $n=2+10+18$. This study describes the data set (approximately 16 hours of audio recordings and 145 pages of transcript) and suggests the possibilities for its interpretation. The final result will be a theory about key factors behind the succesful engagement of volunteering parents into a day-to-day life of the school.
\end{abstract}

Keywords: volunteering parent, the international school, semi-structured interviews

\section{Velký obraz: role př́padové studie Mezinárodní školy v Haagu v celkovém designu disertačního výzkumu}

Př́padová studie Mezinárodní školy v nizozemském Haagu (dále jen PS1) chce prozkoumat, jak „funguje“ téma rodičovských dobrovolníků v hloubi školy. Výsledkem bude př́běh, jehož děj je nesen interakcemi tři skupin aktérů: vedením školy, učiteli a rodiči-dobrovolníky. Intepretací různých rovin a motivů tohoto „příběhu“ by měla vzniknout teorie o tom, které faktory jsou klíčové pro úspěšnou spolupráci (této konkrétní) školy s rodičovskými dobrovolníky. 
Aby však byla teorie relevantní pro české čtenáře, ověří ji druhá fázei výzkumu v podmínkách PS2, čili v rámci př́ípadové studie vybrané české školy. Specifickým záměrem PS2 bude zjistit optikou nalezené teorie, jak a proč funguje či nefunguje dané téma $\mathrm{v}$ českých podmínkách, př́ípadně které z faktorů zjištěných v PS 1 jsou pro české aktéry v PS2 přijatelné a které nikoliv.

\section{Výřez z velkého obrazu: Mezinárodní škola v Haagu}

Tento příspěvek chce informovat pouze o dílčích výsledcích práce provedené na PS1. Měl by vydat počet $\mathrm{z}$ toho, na co se výzkum $\mathrm{v}$ této fázi ptá, jaká jsou (v literatuře) vodítka pro volbu metod, jak vypadá jimi získaný datový soubor a jaké jsou očekávané výsledky.

\subsection{Výzkumné otázky}

PS1 hledá odpověd' na tyto otázky:

1. Kdo jsou jednotliví aktéři a jak se na půdě školy poprvé setkali /dále setkávají?

2. Jak, proč a s jakým výsledkem ovlivňují jednotlivé skupiny aktérů chování ostatních skupin aktérů?

3. Jaké chování/kterých aktérů je kladně hodnoceno ostatními aktéry?

Vztah mezi otázkami je hierarchický $v$ tom smyslu, že odpovědi by měly postupovat od deskripce u (I) přes naraci (II) až po závěrečnou interpretaci (III), která umožní jakýsi „,induktivní skok“ od dat k teorii. Výsledná teorie zformuluje faktory úspěchu spolupráce školy s rodičovskými dobrovolníky. Tento záměr ilustruje tabulka 1.

Tabulka 1

Otázky, metody a záměr PS1

\begin{tabular}{|ll|}
\hline Otázky & $\begin{array}{l}\text { Metoda získání } \\
\text { odpovědi }\end{array}$ \\
\hline $\begin{array}{l}\text { 1. Kdo jsou aktéři, jak } \\
\text { se na pủdě školy setkali } \\
\text { a nadále setkávají? }\end{array}$ & $\begin{array}{l}\text { Dlouhodobé } \\
\text { zučastněné } \\
\text { pozorování, } \\
\text { polostruktur. } \\
\text { rozhovory }\end{array}$ \\
$\begin{array}{l}\text { 2. Jak a proč ovlivňují } \\
\text { skupiny aktérů chování } \\
\text { ostatních skupin aktérů? }\end{array}$ & $\begin{array}{l}\text { exploratorní } \\
\text { analýza získaných } \\
\text { dat }\end{array}$ \\
$\begin{array}{l}\text { 3. Jaké chování/ kterých aktérů } \\
\text { je oceňováno ostatními? }\end{array}$ & $\begin{array}{l}\text { hledání faktorů - } \\
\text { "induktivní skok" } \\
\text { od dat k teorii }\end{array}$ \\
\hline $\begin{array}{l}\text { Záměr: nalezení klíčových faktorů úspěchu spolupráce školy s } \\
\text { rodičovskými dobrovolníky }\end{array}$ & \\
\hline
\end{tabular}




\subsection{Voditka pro volbu metod (z literatury)}

Téma rodičovských dobrovolníků bude zpracováváno jako jedna z konkrétních podob participace rodičů na vzdělávání dětí. Empirické zkoumání participace rodičů či jejich zapojení $^{1}$ se ovšem pojí $\mathrm{s}$ metodologickými riziky, plynoucími z komplexity a vícedimenzionality obou pojmů. $\mathrm{V}$ anglicky psané odborné literatuře jsou někdy užívány synonymně, avšak častěji je participace chápána jako pojem užší - rozumí se jím zapojení rodičủ do aktivit školy, nikoliv to, jak se rodiče do vzdělání dítěte zapojují doma. Participace také nemíŕi ku prospěch vlastního dítěte, nýbrž školy či třídy jako celku (Smit a Driessen, 2008). Pojmy vstoupily do odborné literatury v 60. letech minulého století, kdy v Západní Evropě a Spojených státech vznikaly programy na angažování rodičů ze sociálně znevýhodněného prostředí s cílem zlepšit školní výsledky jejich dětí. Projekty byly nákladné a bylo potřeba zjistit efektivitu vynaložených peněz, proto v literatuře i praxi byla nejčastěji zkoumána efektivita v podobě otázky, jak ovlivňuje zapojení rodičů školní výsledky dětí. $\mathrm{V}$ odpovědích na tuto otázku nalezneme v literatuře vznikající do devadesátých let naprosto rozporná empirická zjištění (Desforges \& Abouchaar, 2003, s. 17).

Od devadesátých let se objevují studie založené na kvantitativní analýze dat z dotazníků. Další zpřehlednění přinášejí počátkem století metaanalýzy a přehledové studie druhotně zpracovávající data z kvantitativních studií, někdy s využitím statistických metod. Ptají se po efektivitě té či oné podoby rodičovského zapojení a jejím vlivu na školní výsledky a chování dětí, ani ony však nepřinášejí jednoznačné závěry (Sande, 2010).

Vedle metaanalýz zkoumajících efekty rodičovské participace nabízí literatura i přehledové studie zkoumající metodologii jiných studií. Joep Bakker a Eddie Denessen z Institutu behaviorálních věd Univerzity v Nijmegenu analyzovali v roce 2007 celkem 12 kvantitativních studií zpracovávajících data získaná dotazníky a na konferenci ERNAPE v Nikósii ${ }^{2}$ a doporučili nejvhodnější metody pro další empirický výzkum rodičovské participace. Bakker a Denessen se ptali po 1) reliabilitě, 2) interpretaci a 3) validitě získaných dat. Zjištěnou reliabilitu označují za uspokojivou, $\mathrm{u}$ interpretace radí k obežretnosti, ale zásadně zpochybňují validitu dat získaných od rodičů dotazníkem. Argumentují tím, že rodiče v tzv. self-reports, tedy dotaznících, v nichž jedinec hodnotí své vlastní chování, systematicky zkreslují údaje. Bakker a Denessen proto doporučili pro zkoumání rodičovské participace použít kvalitativní výzkum, zejména hloubkové rozhovory. „Intenzivními rozhovory s rodiči bychom snad dokázali odhalit skrytější podoby zapojení rodičů do vzdělávání jejich dětí,“ uzavírají citovaní autoři.

Případová studie Mezinárodní školy v Haagu respektuje výše uvedené doporučení v tom, že data získává především hloubkovými rozhovory, oproti doporučení však přesto trianguluje informanty (kromě rodičů přibírá učitele a vedení školy) v naději, že tím zmnoží úhly pohledu na zkoumanou problematiku.

\subsection{Popis získaného datového souboru z PS1}

Ve zkoumané Mezinárodní škole v Haagu proběhly během dvou měsíců, tj. od dubna do června, polostrukturované rozhovory, triangulované podle informantů - viz obrázek 1 .

\footnotetext{
${ }^{1} \mathrm{~V}$ anglicky psané literatuře „parental participation“ a „parental involvement“, v nizozemsky psané literatuře „,ouderparticipatie“ a ,ouderbetrokkenheid“.

${ }_{2}^{2}$ European Research Network About Parents in Education sdružuje výzkumníky v oblasti participace rodičů na vzdělávání dětí.
} 


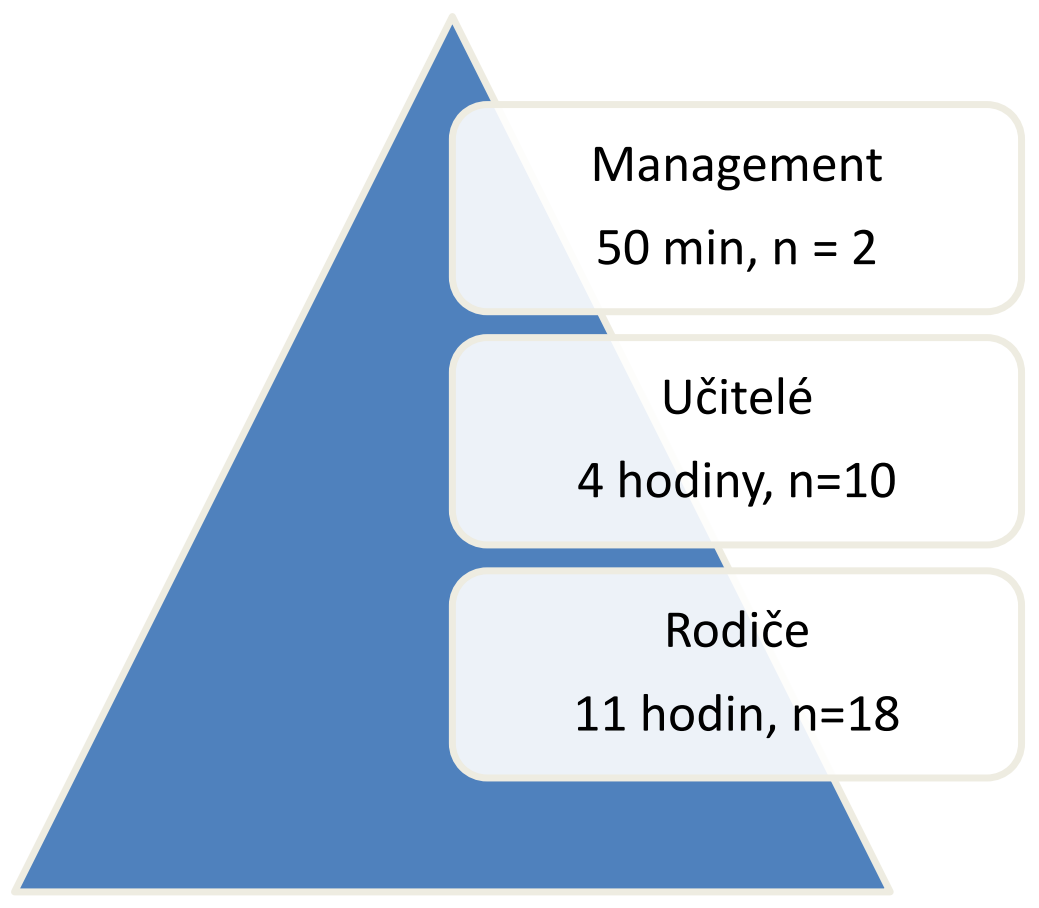

Obrázek 1. Triangulace informantů s naznačenou hierarchií.

Celkový počet informantů byl 30, z toho 18 byli aktivní rodiče-dobrovolníci, 10 učitelé v nejnižších ročnících a 2 zástupci vedení školy. Rozhovory byly přepsány, vzniklo 145 stran (anglického) transkriptu a asi 16 hodin audiozáznamu.

\section{4. Očekávané výsledky}

Je těžké předjímat interpretace a hovořit o očekávaných výsledcích (faktorech úspěchu) ve chvíli, kdy data zdaleka nejsou dostatečně zpracována. Užitečnější bude zmínit existenci jistého „vstupního kapitálu“ pro analýzu dat, totiž fakt, že rozhovorům předcházely 2 roky zúčastněného pozorování, kdy autorka postupně zpracovávala a konceptualizovala vlastní zkušenost rodiče-dobrovolníka. Výrazem této zkušenosti pak byla navržená „kostra“ polostrukturovaných rozhovorů s ostatními aktéry sledovaných procesů. $\mathrm{Na}$ detailní analytickou reflexi této zkušenosti zde není místo, nicméně je pravděpodobné, že zvyšuje teoretickou citlivost, usnadnila sběr dat, zkvalitní interpretace a do jisté míry vynahradí handicap osamělého výzkumníka.

\section{Od výřezu zpět k velkému obrazu}

Česká literatura k tématu ukazuje, že samotná komparace dvou př́ípadových studií zaměřených na dané téma by asi mnoho plodů nevydala. V české základní škole totiž rodičovský dobrovolník jako hlavní postava příběhu chybí (Šed’ová, 2009), nebo se vyskytuje výjimečně a přináší frustraci, která potenciálně ohrožuje chod školy (Dvořák et al., s. 137139). Komparace by tedy vedla ke konstatování výskytu či absence sledovaných jevů a navíc by mohla tlačit k normativnímu hodnocení typu „A je lepší, B je horší.“

Jako slibnější cesta se proto jeví získat v rámci české případové studie PS 2 prímo od aktérů - rodičů, učitelů, vedení - hodnocení přijatelnosti jednotlivých faktorů vyextrahovaných 
z PS1. Do celkového designu tak ve fázi PS2 přibude nová výzkumná otázka 4: které faktory úspěchu spolupráce školy s rodičovskými dobrovolníky připadají přijatelné českým aktérům? Přiměřenou metodou získání odpovědi by mohly být ohniskové rozhovory se skupinami aktérů. Vzniklý datový soubor by umožnil další úroveň interpretace a mohl by vést k závěru, které ze zjištěných faktorů by mohly fungovat v realitě konkrétní české školy jako organizace.

Př́nonom navrhovaného designu založeného na dvojpř́ipadové studii je mezinárodní kontext, v němž problematika rodičovských dobrovolníků dosud nebyla v ČR zkoumána. Zjevným limitem je fakt, že závěry případových studií nelze generalizovat. Lze ovšem doufat, že směs toho nového, co takto rozvržený výzkum zjistí a toho, co naopak zjistit nedokáže, bude inspirací k dalšímu zkoumání problematiky.

\section{Seznam literatury}

Bakker, J., \& Denessen, E. (2007). The concept of parent involvement. Some theoretical and empirical considerations. In H. Phtiaka, \& S. Symeonidou (Eds.), Schools and families in partnership: looking in the future. Nicosia: ERNAPE.

Desforges, C., \& Abouchaar, A. (2003). The impact of parental involvement, parental support and family education on pupil achievements and adjustment: A literature review. London department for Educational Skills.

Epstein, J. L. (1996). Perspectives and previews on research and policy for school, family and community partnerships. In A. Booth \& J. Dunn (Eds.), Family-school links: how do they affect educational outcomes? Hillsdale, N. J.: Erlbaum.

Rabušicová, M., et al. (2004). Škola a /versus/ rodina. Brno: MU.

Sande, M. van de. (2010). De leerkracht als opvoeder tot ouderbetrokkenheid. In M. Hogenes \& C. de Booys (Eds.), De leerkracht als opvoeder. Den Haag: Sdu Uitgevers bv.

Smit, F., Driessen, G., et al. (2008). Ouders en innovatief onderwijs. Nijmegen: ITS.

Šed'ová, K. (2009). Tiché partnerství. Vztahy mezi rodiči a učitelkami. Studia paedagogica, 14(1), $27-51$.

Dvořák, D., et al. (2010). Česká základní škola. Vícepř́padová studie. Praha: Karolinum.

\section{Kontakt}

Mgr. Magdalena Marešová

Technická univerzita v Liberci

Fakulta př́rodovědně-humanitní a pedagogická, Katedra pedagogiky a psychologie

Voroněžská 13, 46117 Liberec 1

e-mail:magdalena.maresova@centrum.cz

\section{Bibliografické údaje}

Marešová, M. (2011). Jak to ta škola dělá? (Klíčové faktory úspěšného zapojení rodičovských dobrovolníků do každodenní práce školy. Exploratorní př́ípadová studie Mezinárodní školy v Haagu). In T. Janík, P. Knecht, \& S. Šebestová (Eds.), Smišený design v pedagogickém výzkumu: Sbornik přispěvki̊ z 19. výroční konference České asociace pedagogického výzkumu (s. 474-478). Brno: Masarykova univerzita.

Dostupné z: http://www.ped.muni.cz/capv2011/sbornikprispevku/maresova.pdf

doi: 10.5817/PdF.P210-CAPV-2012-38 